\title{
Phelps Lake and Jim Burt: Two Middle Woodland Period Mounds in Northwestern Louisiana
}

Jeffery S. Girard

Northwestern State University of Louisiana

Follow this and additional works at: https://scholarworks.sfasu.edu/ita

Part of the American Material Culture Commons, Archaeological Anthropology Commons, Environmental Studies Commons, Other American Studies Commons, Other Arts and Humanities Commons, Other History of Art, Architecture, and Archaeology Commons, and the United States History Commons

Tell us how this article helped you.

This Article is brought to you for free and open access by the Center for Regional Heritage Research at SFA ScholarWorks. It has been accepted for inclusion in Index of Texas Archaeology: Open Access Gray Literature from the Lone Star State by an authorized editor of SFA ScholarWorks. For more information, please contact cdsscholarworks@sfasu.edu. 


\section{Phelps Lake and Jim Burt: Two Middle Woodland Period Mounds in Northwestern Louisiana}

\section{Creative Commons License}

\section{(c) (1) \&}

This work is licensed under a Creative Commons Attribution-NonCommercial 4.0 International License 


\title{
PHELPS LAKE AND JIM BURT: TWO MIDDLE WOODLAND PERIOD MOUNDS IN NORTHWESTERN LOUISIANA
}

\author{
Jeffrey S. Girard \\ Northwestern State University of Louisiana
}

\section{Introduction}

Clarence Webb (Fulton and Webb 1953; Webb 1984) defined the pre-Caddoan Bellevue focus on the basis of investigations at several isolated mounds located in upland settings in northwestern Louisiana (Figure 1). With the exception of the Bellevue Site (16BO4), little detailed information is available about these mounds. Most were excavated many years ago and few notes, photographs, or other records exist. This paper describes the results of recent cleaning of an old exca- vation trench through one of the Bellevue focus sites - the Phelps Lake Mound (16BO24). The work has provided a relatively detailed look at the mound strata. A radiocarbon assay on a sample of charcoal underlying the mound constitutes one of the few chronometric dates from a Bellevue focus context. Also discussed briefly is the Jim Burt Site (16BO23), where a radiocarbon assay was obtained on charcoal recovered near the mound.

\section{The Phelps Lake Site (16BO24)}

\section{Introduction}

The Phelps Lake Site initially was recorded by Webb and described in his summary of the Bellevue focus (Webb1984). He reported that the mound had been partially excavated by Boy Scouts in 1960 under the direction of Robert Fulton and Michael Beckman. Webb visited while the work was being carried out. He noted that the mound - was constructed of mixed

fill and showed no evidence of construction phases or of sub-mound midden. No burials, cremations, hearths, or other features were found. The few pottery sherds seemed consistent with Bellevue ceramics, mostly plain, clay-grit or bone tempered, and slightly 
thick, with one or two indefinitely incised sherds. The lithics were also scarce, but Gary and Ellis type points were found (Webb 1984:265).

In the 1980s, Louis Baker of the Louisiana Archaeological Society found a small mound in the same vicinity, but it was not clear that it was the site described by Webb. Baker and I visited the site in February 2001 with Wilton Corley of Benton, Louisiana. Corley had participated in the scout excavations and confirmed that Baker's site was the Phelps Lake Mound. Shortly thereafter, I found notes and a sketch map in the files at Northwestern State University describing a mound near the town of Plain Dealing, Louisiana. The notes were written in April 1967 by Cynthia Kittler, a former student at Northwestern State University of Louisiana. Kittler stated that:

The Plains Dealing site was found by Mr. Ardis Manry, Justice of the Peace in Plain Dealing, about 1955. He enlisted the aid of Dr. Clarence Webb and two geologists and a scout troop who excavated the site. Only three pieces of pottery were found and one fish vertebra. The mound also yielded three bundle burials, each on a different level. Some projectile points were found in the area near the mound. Disposal of the artifacts and bodies is un-

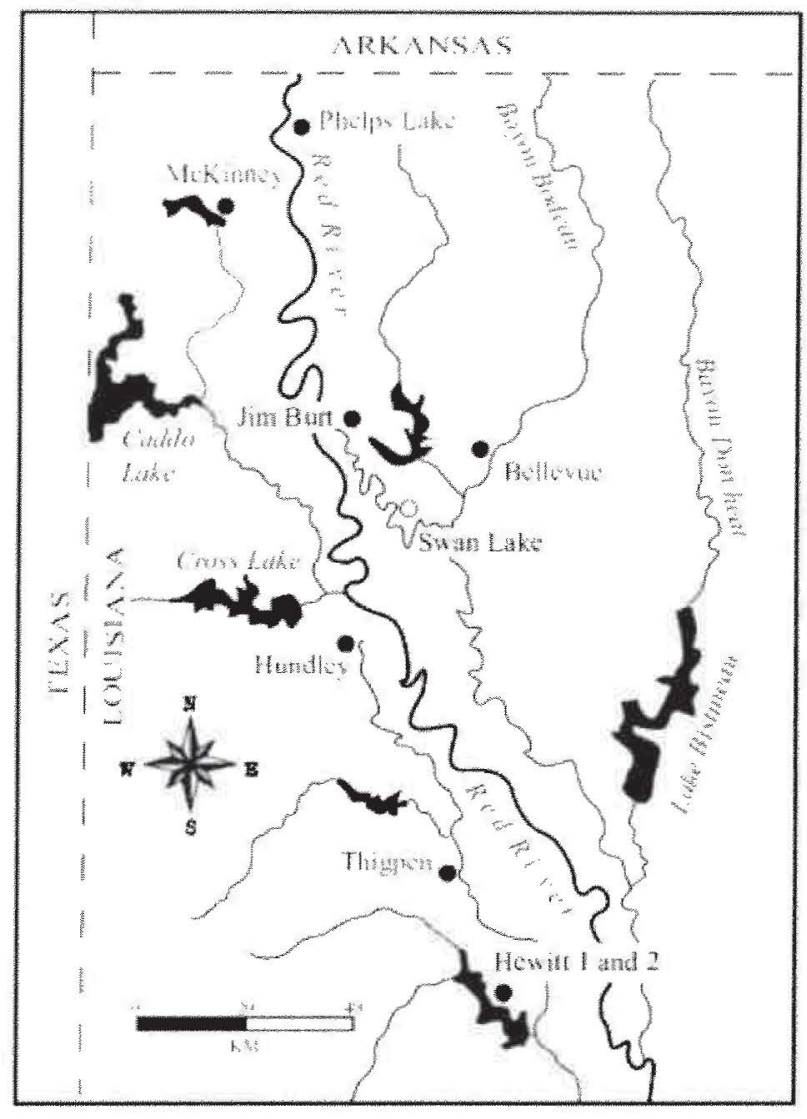

Figure 1. Locations of recorded Bellevue focus mounds and the Swan lake site.

known. Dr. Webb might be able to supply this information. All I found was a piece of charcoal and it is doubtful that much remains at the mound.

Her sketch map of the mound and its setting made it clear that this was the same site recorded by Baker and described by Webb as the Phelps Lake Mound. Her report of the burials does not concord with Webb, but it is possible that they were discovered after Webb visited the site. On Kittler's sketch map, a burial is plotted on 
the east side of the excavation trench, near the center of the mound.

When we returned to the site in 2001, the area was covered with small trees and dense underbrush. The mound appeared much as Kittler drew and described it in 1967; no additional damage was evident.
The trench profiles were slumped and covered with moss and other vegetation. The base of the trench was covered with a thick layer of humus and leaf litter. We decided that this was a rare opportunity to obtain much needed information about the structure of a Bellevue focus mound, and to recover charcoal for a radiocarbon date as well.

\section{Description of the Site}

The Phelps Lake mound was constructed in an unusual topographic setting. It is situated near the base of a slope to a high ridge overlooking the Red River floodplain (Figure 2). The top of the ridge is approximately $122 \mathrm{~m}$ above sea level. The slope drops steeply about $46 \mathrm{~m}$, then levels to the floodplain, the margins of which are approximately $61 \mathrm{~m}$ above sea level. The mound is on the lower, more

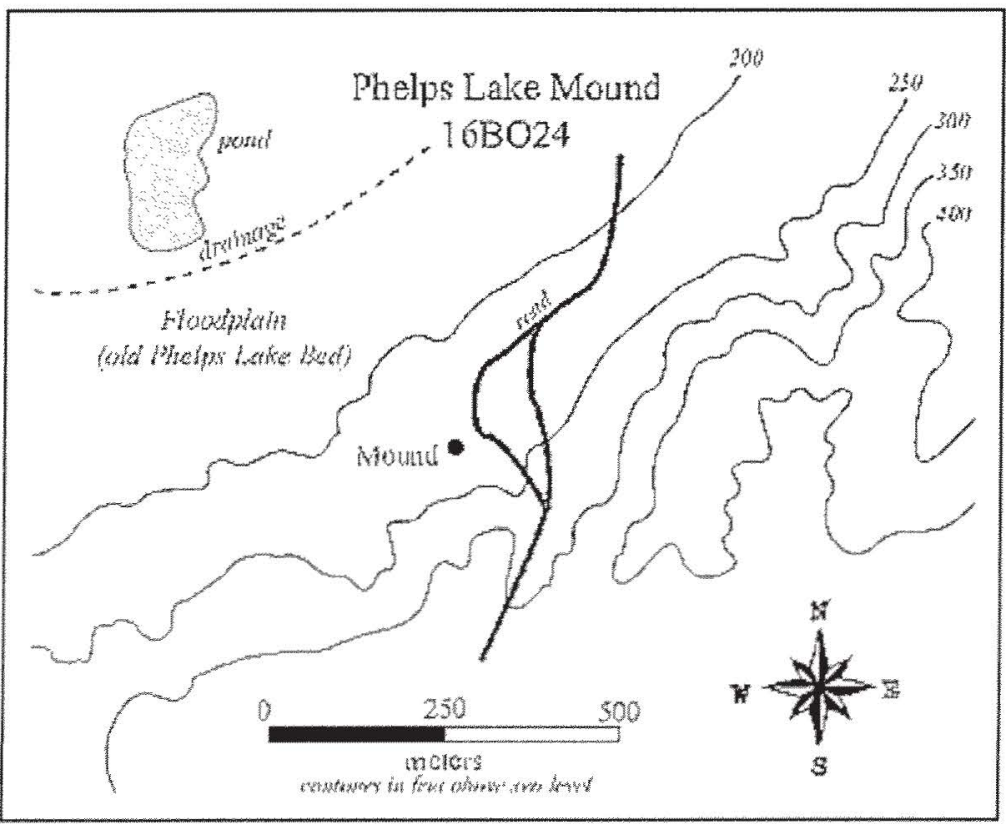

Figure 2. Topographic setting of the Phelps Lake Mound. level portion of the slope at an elevation of about $70 \mathrm{~m}$ above sea level. Early nineteenth century maps indicate that a large lake, known as Phelps Lake, was present along the edge of the floodplain in this area. Phelps Lake is one of many marginal floodplain lakes in the Red River floodplain. These often are called "raft lakes" because they were at least partially formed from blockages of the main channel due to bank slumping and fallen trees. Large historically documented lakes such as Caddo or Ferry Lake and Sodo Lake are probably less than 500 years old (Albertson and Dunbar 1993:40-41). However, it is possible that rafts of varying size and location formed and dispersed throughout late prehistoric times in the Red River floodplain. Unfortunately, we have no geomorphic data regarding the history of Phelps Lake.

Because the Phelps Lake mound was built on a slope, 


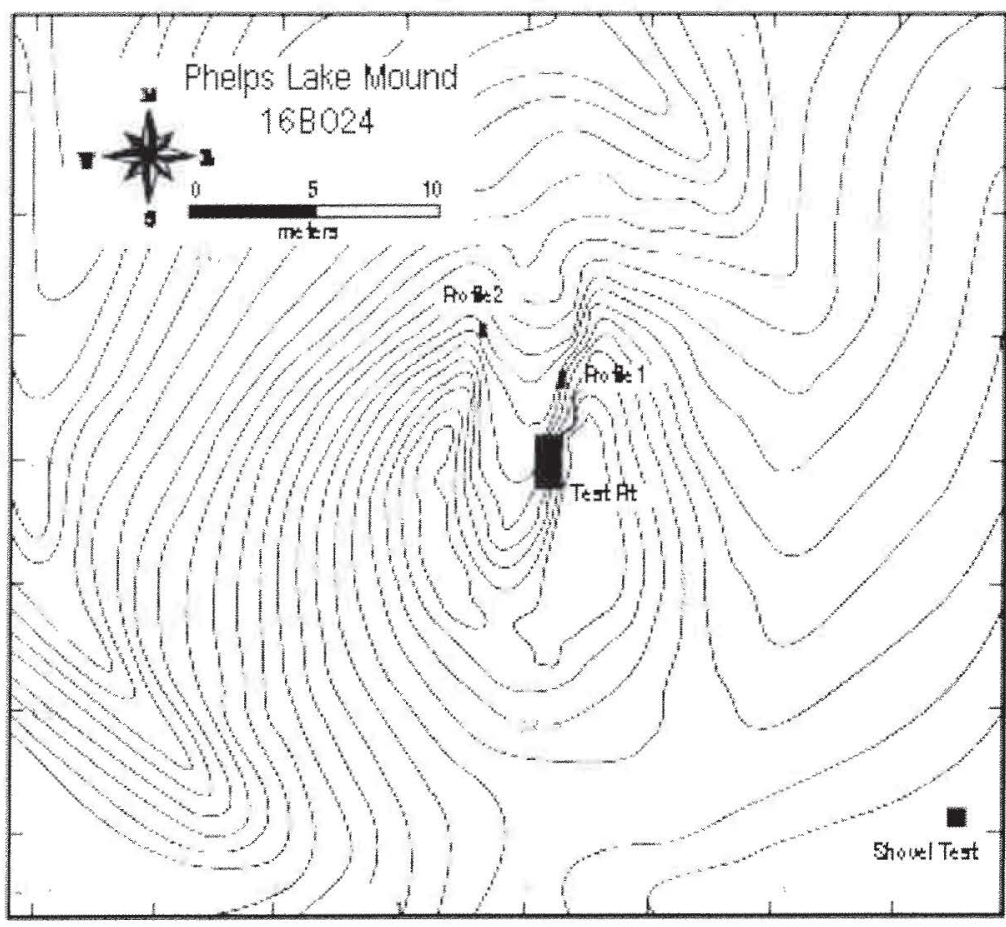

Figure 3. Contour map of the Phelps Lake Mound.

It begins downslope on the north side and extends south into the mound, but not completely through it. There is no record regarding the number of excavators involved in digging the trench, nor how long it took to complete.

\section{Methods of Investigation}

We concentrated our investigations on the upper portion of the eastern profile of the trench near the center of the mound where Kittler showed a burial on her sketch map. We first cleaned the top of the profile and then excavated a 1-x-2 m test

it is only about $80 \mathrm{~cm}$ tall on the southeast side, but almost $2.5 \mathrm{~m}$ high on the northwest (Figures 3 and 4 ). The mound is a little over $20 \mathrm{~m}$ long on the north-south axis, and 12 to $15 \mathrm{~m}$ wide, making it smaller than the Bellevue Mound (16BO4), but of comparable size to the other Bellevue focus mounds reported by Webb. As much as $40 \mathrm{~cm}$ of backdirt from the trench excavation is present on top of the mound making it seem slightly taller than its original height.

The trench is approximately $4 \mathrm{~m}$ wide.

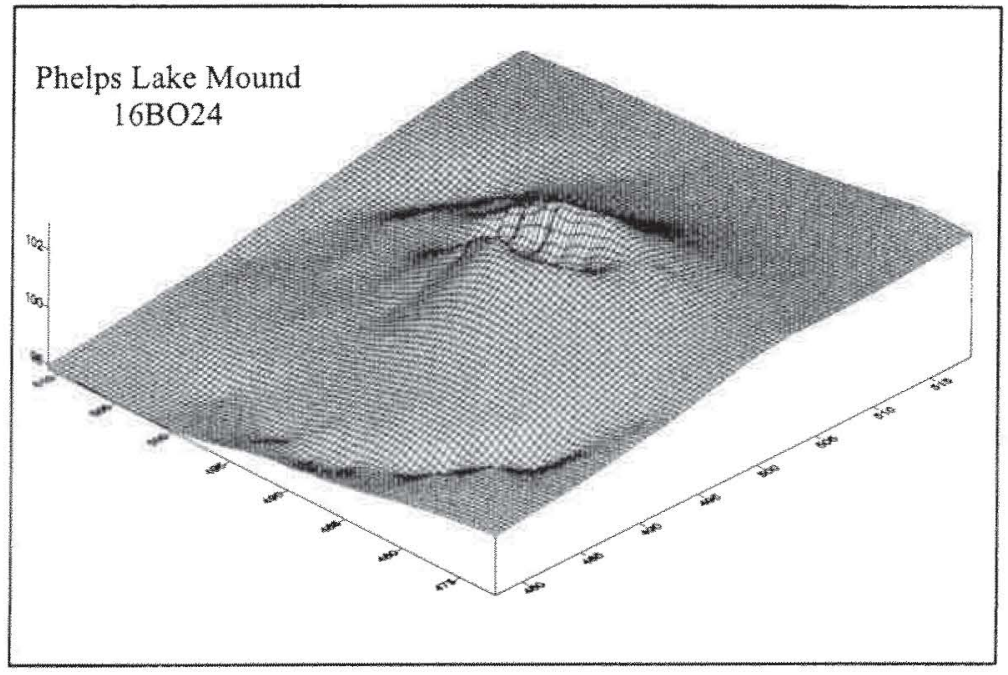

Figure 4. Wire-frame model of the Phelps Lake Mound. 


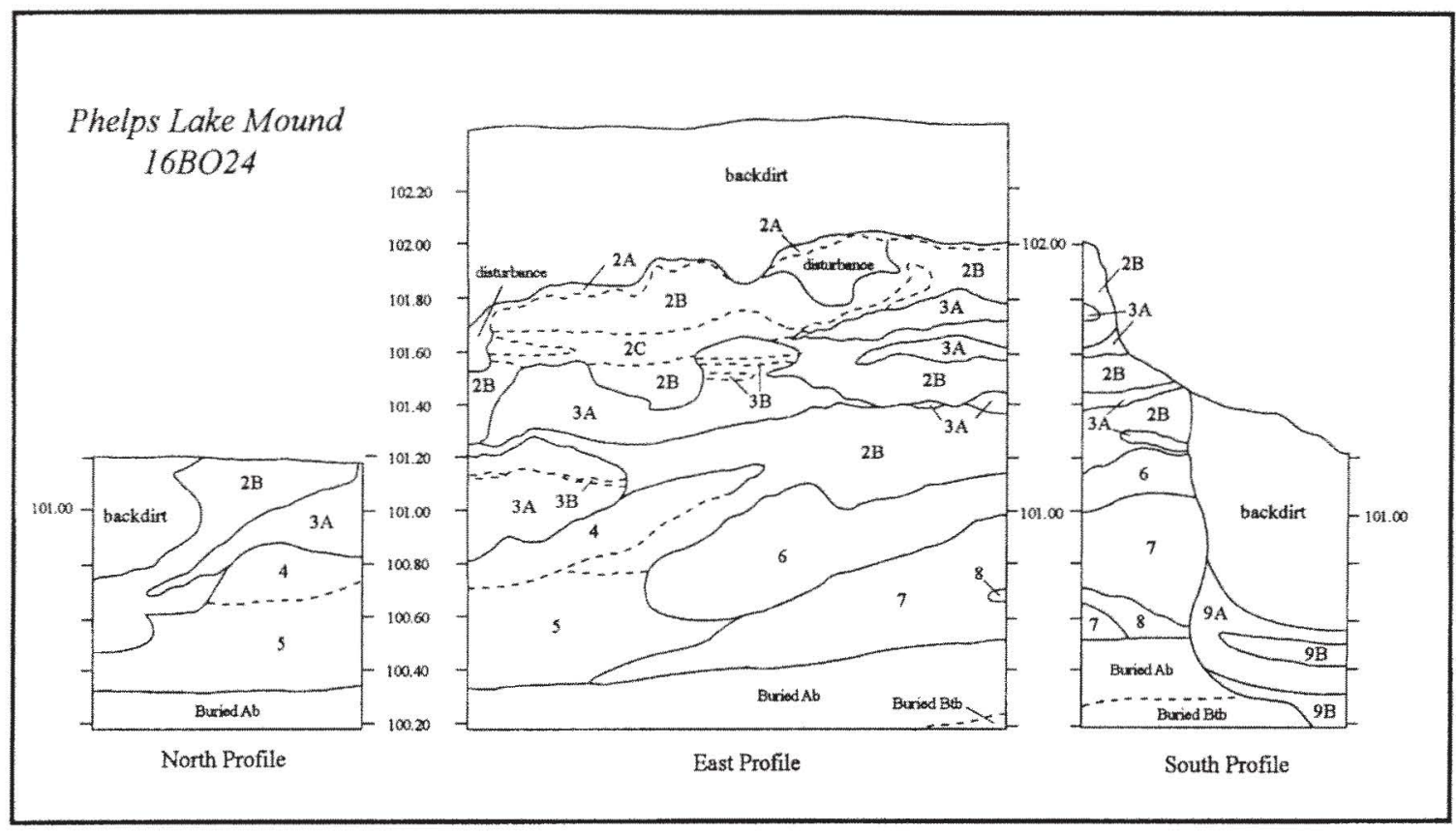

Figure 5. Profiles of the test pit, Phelps Lake Mound.

mound fill, and into the submound deposits. We cleaned a $50 \mathrm{~cm}$ wide portion of the exposed profile $2 \mathrm{~m}$ north of the trench where the loading sequence was not as complex (Profile 1; Figure 3). Thurman Allen, soil scientist with the Natural Resource Conservation Service, made a detailed description of this profile. We also exposed a $50 \mathrm{~cm}$ wide profile (Profile 2) at the north end of the mound, on the west side of the trench. Finally, we attempted to locate habitation debris in the area that might relate to use of the mound. Baker dug approximately 20 bucket auger tests in areas downslope from the mound, but none of the tests yielded artifacts or other signs of occupation. We excavated one $50-x-50 \mathrm{~cm}$ shovel test in a relatively level area east of the mound and recovered a single chert flake.
Description of the Mound and Natural Deposits

Figure 5 is a drawing of three profiles the $1-\mathrm{x}-2 \mathrm{~m}$ trench in the center of the mound (the west profile contained only slumped deposits from the trench excavation). Tables 1 and 2 are descriptions of the sequence of deposits in Profiles 1 and 2.

Variations in the deposits relate both to different parent materials used for mound construction, and the subsequent weathering of these materials. The basic depositional sequence visible in the profile from top to bottom is: (1) the submound natural soil; (2) an inner clay loam mound present only in the excavation unit; (3) an outer mound consisting of multiple lenses and strata of fine sandy loam; and (4) backdirt from the trench. 
Table 1. Description by Thurman Allen of deposits in Profile 1, Phelps Lake Mound.

\begin{tabular}{|l|l|l|}
\hline Horizon & Level & Description \\
\hline Overburden & $101.58-100.98$ & mixed fine sandy loam; backdirt from trench \\
\hline A & $100.98-100.82$ & $\begin{array}{l}\text { dark grayish brown (10YR4/2) fine sandy loam; weak medium subangular blocky structure, } \\
\text { very friable }\end{array}$ \\
\hline $\mathrm{E}$ & $100.82-100.61$ & $\begin{array}{l}\text { pale brown (10YR6/3) fine sandy loam; weak medium subangular blocky structure; very } \\
\text { friable; few fine to medium size 'B' bodies in the lower part of the E horizon; thin, clayey } \\
\text { lamella on lower sideslope }\end{array}$ \\
\hline $\mathrm{Bw}$ or Bt & $100.61-100.38$ & yellowish red (5YR4/6) loam; weak medium subangular blocky structure; friable \\
\hline $\mathrm{BC}$ or C & $100.38-100.01$ & strong brown (7.5YR4/6) fine sandy loam; weak medium structure; very friable \\
\hline $\mathrm{Cl}$ & $100.01-99.80$ & red (2.5YR4/6) loam; weak medium subangular blocky structure; friable \\
\hline $\mathrm{C} 2$ & $99.80-99.70$ & brown (7.5YR5/4) fine sandy loam; weak medium subangular blocky structure; very friable \\
\hline 2Ab & $99.70-99.55$ & brown (7.5YR4/3) fine sandy loam; weak medium subangular blocky structure; very friable \\
\hline 2Eb & $99.55-99.46$ & brown (7.5YR5/4) fine sandy loam; weak medium subangular blocky structure; very friable \\
\hline 2Btb & $99.46-99.33$ & yellowish red (5YR4/6) sandy clay loam; moderate medium subangular structure; friable \\
\hline
\end{tabular}

Table 2. Description of deposits in Profile 2, Phelps Lake Mound.

\begin{tabular}{|l|l|l|}
\hline Horizon & Level & Description \\
\hline Mixed & $100.90-100.48$ & strong brown (7.5YR4/6) fine sandy loam with complex mottling of redder sediments \\
\hline A & $100.48-100.39$ & brown (7.5YR4/4) fine sandy loam, very friable \\
\hline E & $100.39-100.07$ & brown (7.5YR4/6) fine sandy loam, very friable \\
\hline Bw or Bt & $100.07-99.93$ & yellowish red (5YR4/6) loam, weak blocky structure, friable \\
\hline 2Aeb & $99.93-99.65$ & brown (7.5YR4/6) fine sandy loam, very friable \\
\hline 2Btb & $99.65-99.58$ & dark red (2.5YR4/8) sandy clay loam, moderate blocky structure; friable \\
\hline
\end{tabular}

Beneath the backdirt from the trench excavation, Allen noted substantial soil development in the upper mound deposit (Table 1). The presence of $\mathrm{E}$ and $\mathrm{Bw}$ or $\mathrm{Bt}$ horizons indicates considerable age for the mound. However, these horizons are not as well developed as those present in Archaic period mound sites in northeastern Louisiana (Thurman Allen and Joe Saunders, personal communication). The parent material for these horizons was probably similar to the strong brown loam identified as the $\mathrm{BC}$ or $\mathrm{C}$ horizon in the profile. This sediment probably was simply taken from the upper soil horizons on the surrounding slope. Underlying this was a redder, finer-grained deposit that might be borrowed from $B$ horizon sediments in the surrounding areas. Because of high erosion on the slope, B 
horizons are at, or near, the surface in many areas. Beneath this deposit is another loading episode apparently acquired from upper soil horizon sediments.

Similar soil development is present in Profile 2. The upper part of the profile appears to represent a mixture of slumped and washed in sediments from backdirt and trench fill from upslope. An A horizon, somewhat thinner than that identified in Profile 1, is present below the mixed fill. The A horizon is underlain by $\mathrm{E}$ and $\mathrm{Bw}$ or $\mathrm{Bt}$ horizons. No mound deposits beneath the $\mathrm{B}$ horizon were identified (this profile is near the base of the mound). The buried A horizon looked much like the mound deposits, but was identifiable by the very sharp break with the overlying $B$ horizon of the mound fill.

Soil horizons are not detectable in the test unit ( Figure 5). It appears that sediments from two different sources were used for the upper mound fill. Most widespread is a yellowish red (5YR4/6) (Zone 2B) to red (2.5YR4/6) (Zone 2C) fine sandy loam that seems to correspond to the Bt or Bw horizon noted by Allen in Profile 1. The overlying $A$ and $E$ horizons are not visible suggesting that the upper part of the mound has been removed. An intermittent, thin, wavy organic zone (Zone $2 \mathrm{~A}$ ) is present beneath the backdirt overburden. Several disturbances are visible, probably from trees or old treasure hunter's pits.

Interspersed within the upper mound sediments are loadings of a brown to light brown $(7.5 \mathrm{YR} 5 / 2$ to $7.5 \mathrm{YR} 6 / 4)$ very friable fine sandy loam (Zone $3 \mathrm{~A}$ ). It is not clear where this material was acquired, but soils on the surrounding ridge slope are very complex due to variation in slope and erosion. One auger test west of the mound area encountered similar sediments. The lamellae noted by Allen in the E horizon of the trench profile also are present within the Zone 4 sediments. The lamellae are finer grained and redder $(2.5 \mathrm{YR} 4 / 6)$ than the surrounding sediments and appear to be pedogenic in origin - they consist of fine-grained sediments leached from the overlying deposits.

In the lower portion of the mound, subtle variation in colors and textures (Deposits 4, 5, and 6) appear to represent distinct depositional episodes. The sediments likely are varying mixtures of upper and lower soil horizons from the immediately surrounding slope deposits.

Underlying these deposits was an inner mound consisting of dark red (2.5YR4/6) clay loam with scattered, small $(1-2 \mathrm{~cm})$ mottles of gray fine sand or silt. Numerous ferruginous concretions and small chunks of ferruginous sandstone were present throughout the fill. A lens of brown (7.5YR4/4) fine sandy loam (Zone 8), intrudes into the inner mound in the southeast corner of the unit. No artifacts were recovered from Zones 7 or 8 . It is possible that the parent material for the inner mound was Bt horizon sediments from the surrounding soils, perhaps with some mixture of the upper soil horizons.

The inner mound was present in the excavation unit, but not in the profile to the north. It began $45 \mathrm{~cm}$ south of the 
north edge of the unit and gradually thickened to the south. In the south profile of the excavation unit, it was approximately $40 \mathrm{~cm}$ thick. It appears to have leveled off to the west, toward the mound center and thus may have formed a platform. Unfortunately, the Boy Scout trench destroyed the central portion of the mound and so we cannot be sure. No organic layer was present along the top of the inner mound suggesting that it was not left exposed on the surface for a significant period of time prior to being covered by the outer mound.

The buried soil in the excavation trench was similar to that in Profiles 1 and 2 . However, near the center of the mound, the $\mathrm{Ab}$ horizon was slightly thicker and darker. No artifacts were recovered from the deposit. However, flecks of scattered charcoal were collected and submitted for radiocarbon analysis to the Center for Isotope Studies at the University of Georgia. An age of $1950 \pm 40$ B.P. (UGA9765; charcoal; $\delta^{13} \mathrm{C}=-27.52 \%$ ) was obtained. Although we cannot attribute the charcoal to cultural activity with certainty, it seems likely to have resulted from land clearing or other activities associated with initial construction of the mound.

Sediments backfilled or slumped into the trench are visible in the upper portion of the south profile on the west side (Figure $5)$. Underlying this fill is a series of lenses that were deposited in a different manner. Four bands of fine sandy loam can be distinguished by color - alternating yellowish red (5YR4/6) and brown (7.5YR5/4) (Zones 9A and 9B). The brown deposits contain fine lenses of redder material. In the field, I interpreted these deposits as representing sediments washed into the base of the Boy Scout trench. However, they clearly differ from the overlying material that characterizes the trench fill elsewhere and an alternative explanation is possible.

The sediments might be fill for a pit dug through the inner mound and into the submound deposits by the site inhabitants. Other Woodland period mounds contain shallow submound pits usually with human cremations or burials. Kittler noted that three burials were recovered from the site "each on a different level". It is possible that one of these was within such a pit. If so, the pit must have been dug from the surface of the inner mound or higher. It also is possible that the Boy Scouts did not completely excavate the fill from this pit and it extends south of our excavation unit.

The lens of sandy loam (Zone 8) within the inner mound also is curious. It is possible that it represents the covering of something - perhaps a human burial or cremation as well. In this instance, the burial would have been simply placed on the pre-mound surface, then covered by the sandy loam and remaining sediments of the inner mound. This situation would be similar to that at the Bellevue site where burials were present both on an inner platform and in a pit underlying the mound (Fulton and Webb 1953; Webb 1984).

Artifacts

Artifacts recovered during the investiga- 
tions were limited to two chert flakes from the excavation trench, and two sherds during exposure of Profile 2 at the north end of the trench. One of the sherds is typical of Williams Plain pottery that is generally associated with this period. It is thick ( $8 \mathrm{~mm}$ ) and has coarse grog and grit temper. The second sherd appears to represent a vessel appendage or perhaps a pipe fragment. It also has coarse grog and grit temper.

\section{The Jim Burt Mound (16BO23)}

Webb (1984:264-5) also initially described the Jim Burt Mound. He reported that a trench was excavated in the mound by Robert Fulton, Robert Scott, and Mike Beckman. The excavations were stopped when recent burials were encountered. The mound deposits were described as a single homogeneous zone of "sand-clay". Webb reported that a few sherds were found at the site. The sherds had clay, clay-grit, and bone temper. Most were plain, but a few had irregularly incised lines.

The Jim Burt mound is situated on a Pleistocene terrace remnant, directly overlooking the Red River floodplain near the town of Benton (Figure 6). During the nineteenth century, several houses were located along the bluff edge in the area. Scatters of nineteenth century ceramics and other artifacts, as well as several small cemeteries, remain from those occupations. Presently, the mound site is in pasture and the surface is covered by thick grass. The mound has been badly eroded and trampled by cows. The trench excavated in the 1960 s remains

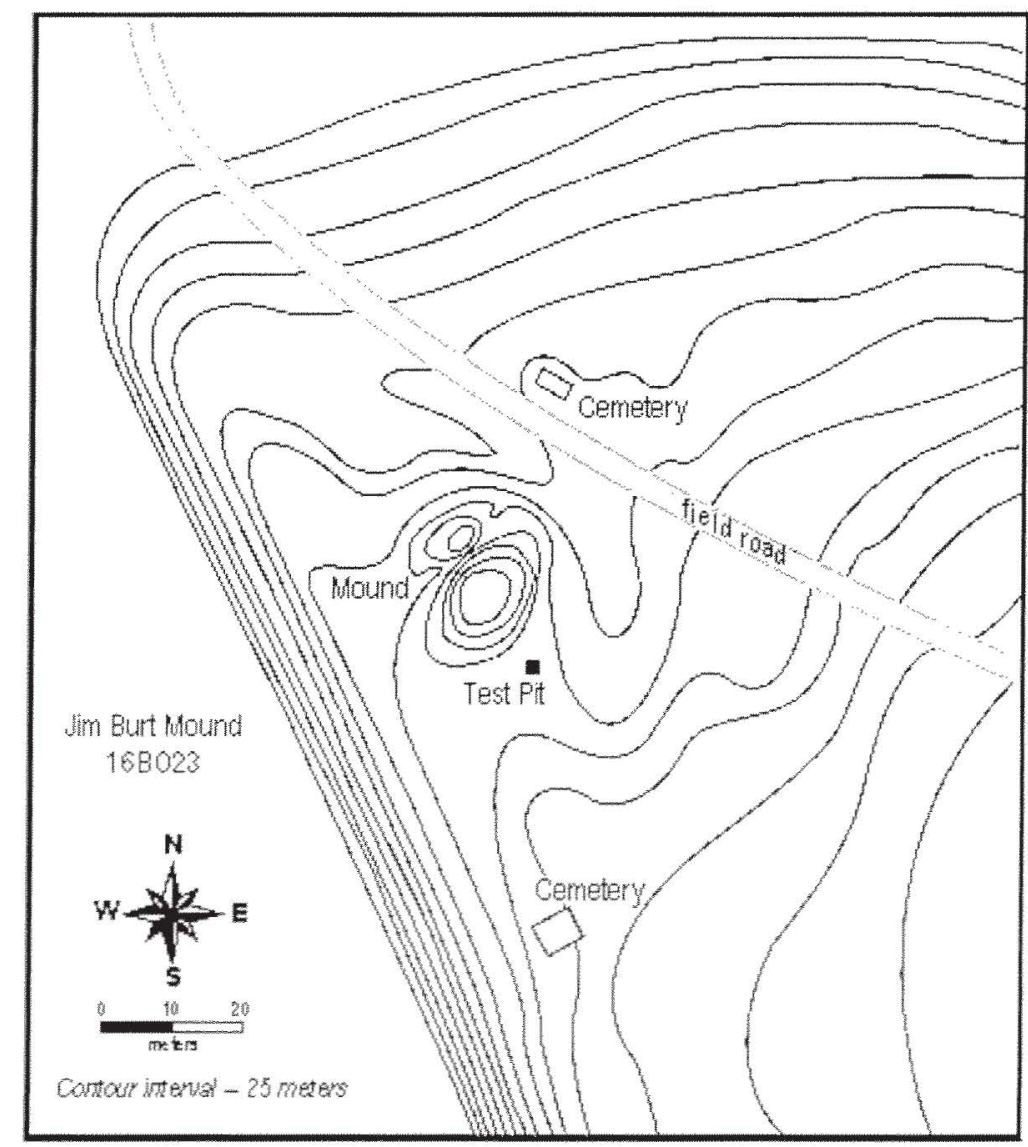

Figure 6. Contour map of the Jim Burt Mound. 
visible. Fragments of nineteenth century head-stones are present around the mound. The mound now is about $1 \mathrm{~m}$ high and 20 to $25 \mathrm{~m}$ in diameter, similar in size to the Phelps Lake mound.

Louis Baker and I visited the site in 1995 and found a Keithville point on the eroded mound surface, and a small stemmed point on the terrace slope north of the mound. We excavated a 1-x-1 m test unit approximately $8 \mathrm{~m}$ southeast of the mound. The upper deposits were approximately $40 \mathrm{~cm}$ thick and consisted of a brown sandy loam. Beneath was reddish-brown sandy loam to a depth of at least $60 \mathrm{~cm}$. Six sherds, 14 flakes, seven chunks of firecracked rock, and four fragments of iron were recovered in the test unit. The iron fragments were recovered in the upper 40 $\mathrm{cm}$ of the deposits. Two of the sherds were recovered between $20 \mathrm{~cm}$ and $40 \mathrm{~cm}$ below the surface. Both are grog-tempered and one has a single incised line. The remaining four sherds were recovered between 40 and $60 \mathrm{~cm}$ below the surface. All have a friable, laminated paste, similar to Tchefuncte pottery from the Lower Mississippi Valley. However, two appear to have clay or grog temper.

Also encountered in the test unit was a large lump of charcoal at approximately $50 \mathrm{~cm}$ below the surface. Although the charcoal was not associated with a pit or other feature, because of its depth and apparent association with early pottery, it was collected for radiocarbon analysis. An age of $2200+1-70$ BP was obtained (Beta8280; charcoal; $\delta^{13} \mathrm{C}=25.5 \%$ ).

Six small sherds along with 14 flakes were recovered in the test unit. Four of the sherds have distinctly laminated paste and are friable. Two of these have clay inclusions that are distinct from the surrounding paste. The other two lack inclusions. These sherds also have surface striations that appear to be impressions of vegetal matter. The remaining two sherds have harder pastes and are grog tempered. One has a single incised line on the exterior surface.

\section{Comments}

Calibrations of the radiocarbon ages from the Phelps Lake and Jim Burt sites are presented in Table 3 and Figure 7. Figure 7 also contains calibrated ages from charcoal at the McKinney Mound (Webb 1984:262-264) and from a deep pit feature at the Swan Lake site (Girard 1995:6-11). All of the radiocarbon ages obtained so far indicate that the Bellevue focus mounds date prior to $\mathrm{AD} 200$ and are roughly contemporary with the Marksville period in the Lower Mississippi Valley. Unfortunately, dates are not available for the Bellevue site (16BO4) located along Bodcau Bayou. The few decorated sherds recovered from the site suggest that occupation might have taken place later than at the other Bellevue focus mounds. However, Schambach (1996) argues that mortuary traits suggest that the mound was constructed early in the Fourche Maline sequence. No dates are available 
Table 3. Calibrations of radiocarbon age from the Phelps Lake and Jim Burt Mounds using CALIB 4.3 (Stuiver et al. 1998)

\begin{tabular}{|l|l|l|l|l|l|}
\hline Site & $\begin{array}{c}\text { Lab No. } \\
\text { Phelps Lake }\end{array}$ & $\begin{array}{c}\text { Radiocarbon } \\
\text { Age (BP) }\end{array}$ & Calibrated Age & One-sigma Age Range & Two-sigma Age Range \\
\hline $\operatorname{sim}$ Burt & Beta-8280 & $1910+/ 40$ & cal AD 82 & $\begin{array}{l}\text { cal AD 34-36 } \\
\text { cal AD 58-130 }\end{array}$ & $\begin{array}{l}\text { Cal AD 4-10 } \\
\text { cal AD 19-221 }\end{array}$ \\
\hline
\end{tabular}

from the Hundley Mound (16CD161), the Hewitt Mounds (16DS7 and 16DS270), or the Thigpen Mound (16DS12). At this point, it appears that a lengthy temporal hiatus occurred in mound construction between about $\mathrm{AD} 200$ and the tenth century AD when construction of the first Caddoan mounds began. Additional investigations of these sites are necessary to ensure that this apparent pattern is not merely a result of the limited nature of our investigations.

Schambach (1982) noted similarities to mounds of apparently similar age found in southwestern Arkansas, and suggested incorporating the Bellevue focus into the Fourche Maline sequence. Extant radio-carbon dates place all of the Bellevue sites within Fourche Maline Periods 2 and 3 which Schambach brackets between $400 \mathrm{BC}$ and $\mathrm{AD}$ 200 (Schambach sites.
2001: Table 1). The interval also roughly corresponds to early Marksville sites to the south and east. In a recent summary McGimsey et al. $(2000: 196)$ place the period between approximately $200 \mathrm{BC}$ and AD 400.

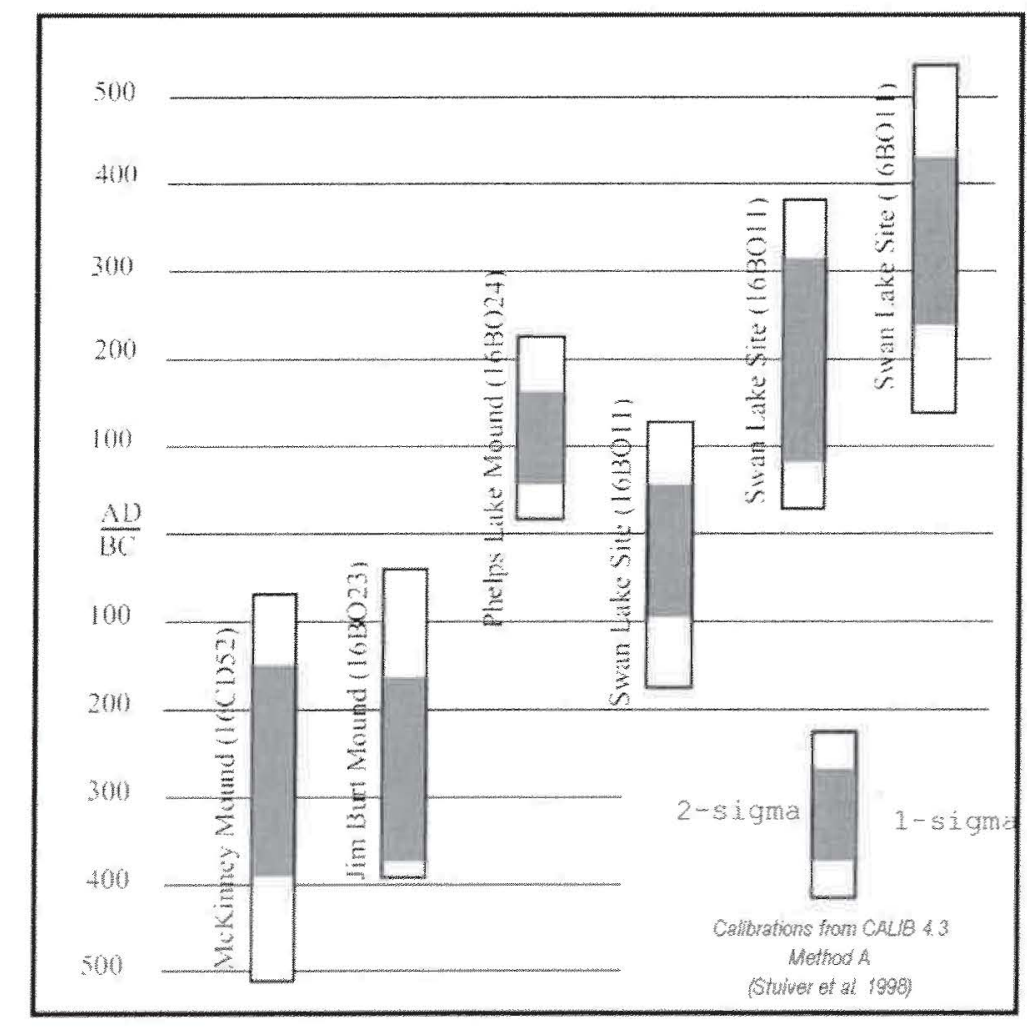

Figure 7. Calibrated radiocarbon ages from Middle Woodland period 
In Louisiana, we have not found many habitation sites associated with these mounds. One contemporaneous occupation appears to be represented by a large pit feature found at the Swan Lake site (16BO11), located near Willow Chute Bayou in Bossier Parish (Figure 1; Girard 1995). Many others undoubtedly exist, but may be buried in floodplain deposits or mixed with later materials and difficult to isolate.

In summary, recent investigations at the Phelps Lake Mound in Bossier Parish, Louisiana have provided a relatively detailed look at deposits in a pre-Caddoan Bellevue focus mound. The investigations also produced a radiocarbon date suggesting that the mound was constructed between $\mathrm{AD} 50$ and $\mathrm{AD}$ 150. A date on charcoal recovered near the Jim Burt Mound was considerably earlier, and corresponds with one reported by Webb from the McKinney Mound. These dates indicate that the Bellevue sites fall in Periods 2 and 3 of the Fourche Maline sequence as defined by Schambach (1982; 2001), and are contemporary with Early Marksville period sites of the Lower Mississippi Valley and Avoyelles Plateau.

\section{Acknowledgments}

Louis Baker assisted in all aspects of the field investigations at both sites. Thanks to Thurman Allen and Joe Saunders for examining the profiles at the Phelps Lake Mound. These projects were conducted through the State of Louisiana's Regional
Archaeology Program, based at Northwestern State University of Louisiana. The projects have been financed with state funds and with federal funds from the National Park Service, U.S. Department of the Interior.

\section{References Cited}

Albertson, Paul E. and Joseph B. Dunbar

1993 Geomorphic Investigation of Shreveport to Daingerfield Navigation Project. Technical Report GL-93-31. U.S. Army Engineer District, Vicksburg.

Fulton, Robert L. and Clarence H. Webb

1953 The Bellevue Mound: A pre-Caddoan site in Bossier Parish, Louisiana. Bulletin of the Texas Archeological and Paleontological Society 24:18-42.

Girard, Jeffrey S.

1995 An Early Ceramic Period Pit Feature at the Swan Lake Site, Bossier Parish, Louisiana. Caddoan Archaeology Newsletter V(4):8-13. 
McGimsey, Charles R., Katherine M. Roberts, H. Edwin Jackson, and Susan L. Scott 2000 Marksville in the Lower Mississippi Valley; New Details and Dates. Appendix C in Archaeology of the Marksville Period, Explorations of Southwest Louisiana Prehistory. Regional Archaeology Program, Management Unit III, 1999/2000 Annual Report. Report on file at the Louisiana Division of Archaeology, Department of Culture, Recreation, and Tourism, Baton Rouge.

Schambach, Frank F.

1982 An Outline of Fourche Maline Culture in Southwest Arkansas. In Arkansas Archeology in Review, edited by N.L. Trubowitz and M.D. Jeter, pp. 132-197. Arkansas Archeological Survey Research Series No. 15, Fayetteville.

1996 The Development of the Burial Mound Tradition in the Caddo Area. Journal of Northeast Texas Archaeology 9:53-72.

2001 Fourche Maline and Its Neighbors: Observations on an Important Woodland Period Culture of the Trans-Mississippi South. The Arkansas Archeologist 40:21-50.

Stuiver, M., P.J. Reimer, E. Bard, J.W. Beck, G.S. Burr, K.A. Hughen, B. Kromer, F.G. McCormac, J. Plicht, and M. Spurk

1998 INTCAL98 Radiocarbon Age Calibration 24,000-0 cal BP. Radiocarbon 40:10411083.

Webb, Clarence H.

1984 The Bellvue Focus: A Marksville-Troyville Manifestation in Northwestern Louisiana. Louisiana Archaeology 9: 251-274. 